\title{
Alexandre Dumas, Le Capitaine Pamphile
}

\section{Lise Sabourin}

\section{(2) OpenEdition}

\section{Journals}

\section{Édition électronique}

URL : http://journals.openedition.org/studifrancesi/27743

DOI : $10.4000 /$ studifrancesi. 27743

ISSN : 2427-5856

\section{Éditeur}

Rosenberg \& Sellier

\section{Édition imprimée}

Date de publication : 31 décembre 2006

Pagination : 619

ISSN : 0039-2944

\section{Référence électronique}

Lise Sabourin, «Alexandre Dumas, Le Capitaine Pamphile », Studi Francesi [En ligne], 150 (L | III) | 2006, mis en ligne le 30 novembre 2015, consulté le 08 novembre 2020. URL : http://

journals.openedition.org/studifrancesi/27743; DOI : https://doi.org/10.4000/studifrancesi.27743

\section{Ce document a été généré automatiquement le 8 novembre 2020}

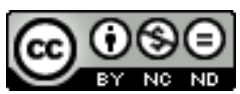

Studi Francesi è distribuita con Licenza Creative Commons Attribuzione - Non commerciale - Non opere derivate 4.0 Internazionale. 


\title{
Alexandre Dumas, Le Capitaine Pamphile
}

\author{
Lise Sabourin
}

\section{RÉFÉRENCE}

ALEXANDRE DUMAS, Le Capitaine Pamphile, édition de Claude schopP, Gallimard, «Folio classique», 2003, pp. 373.

1 Outre une chronologie biographique de l'auteur, une note sur la structure et la temporalité de l'oeuvre, une bibliographie et un index des personnes et personnages, Claude Schopp préface (pp. 7-35) et annote (pp. 313-362) Le Capitaine Pamphile, un des tout premiers romans de Dumas, plus connu par ses drames en 1834, lorsque paraissent dans «Le Journal des enfants» les trois premiers chapitres, sous les titres de JacquesIer et JacquesII; il n'en est déjà plus de même en 1838 quand est publiée la suite (les chapitres IV à XV), Dumas ayant signé par sa nouvelle position de critique dramatique à «La Presse» son tournant vers la prose narrative.

2 Ce roman constitue donc un prélude à la carrière du romancier aux multiples volumes du Drame de la France. La préface de C. Schopp analyse bien cette pochade burlesque, parodique des descriptions romanesques du temps. Cette histoire de ménagerie assemblée dans l'atelier d'un peintre - l'ours Tom, le singe Jacques, Mlle Camargo la grenouille et la tortue Gazelle - révèle à Dumas sa verve et sa liberté. La voix unique du narrateur - même masqué sous son délégataire - entremêle conte pour rire et désespoir au fil de notices nécrologiques des esclaves du ventre que nous sommes plus ou moins tous. "Qui mange qui?» s'applique aussi bien aux indigestions ou famines de ces animaux fort humains qu'à l'appât du gain, à l'exercice du pouvoir, au commerce triangulaire que pratique scrupuleusement (ô ironie dumasienne!) le capitaine Pamphile. Heureusement «l'artiste est l'avenir de l'homme» (p. 33): cette «littérature désédifiante» (p. 34) dépasse la perspective enfantine de la fable animale pour 
présenter le tableau d'un refuge esthétique utopique, consolateur des désillusions de 1830. 